\title{
Utilizing Technologies in Teaching Soft skills: Issues and Challenges
}

\author{
Isdawati Ismail \\ MALAYSIA \\ E-mail: isdawatisimail@gmail.com
}

\begin{abstract}
Technology is inevitable. It evolves every single day. Technology has become a vital aspect of everyone's life especially the youth. To keep up with the modernized world, youth attach themselves to smart phones, online games, social media and many others. Therefore, the modern technology is demanding the lecturers to use these technologies in their teaching. Likewise, employers are demanding for new employees to have sufficient soft skills in order to succeed on the job. Hence there is a crucial need for lecturers to use the technology to enhance their teaching of soft skills. The use of technology is seen to improve and further enhance students' communication, collaboration, problem solving and time management skills. Technology also has the highest potential to increase access to education and improve its quality, especially now that we are geared up towards the 21 st century learning. Lecturers should embrace positively the emergence of the use of technology so that they can reap the benefits of these latest and emerging technologies to make teaching and learning activities more interesting and meaningful to improve soft skills among students.
\end{abstract}

Keywords: Technology, Soft Skills, Education

\section{Introduction}

Technology plays a significant role in the world we live in today. Type-written cover letters and CV's are things of the past as the majority of the employers nowadays accept Virtual Cover Letter (VCL) and Virtual CV to select their future employees. Potential employers would be able to assess the authenticity of the person who is sending the Virtual CV. Besides that, future employers would also be able to see the real person who is applying, rather than the lifeless cover letters or CVs that could easily be copied from the internet but is meaningless to the Human Resource personnels who have to go through hundreds or thousands of applications at a time.Technology enables the candidates to show case their creativity and to highlight their strengths in the most interesting manner. This in turn would increase the chances of getting a job among our graduates. Therefore, it is undeniable that lecturerss has no choice but to accept the pertinent roles that technology plays in elevating the students' soft skills.

Technology has much evolved that it has vastly changed our society. A mushrooming number of people all over the world uses modern technology. One of the most intense changes around the world has been the widespread of information and communication technologies (UNICEF, 2011). As the growth of technology changes the world, it also changes the daily lives of adolescents.

\section{Literature Review}


According to Honey (2005), from the survey that was carried out by Pew Internet and American Life Project which had explored the use of technology among 802 youth aged 12 to 17 , it was revealed that almost $80 \%$ of the teens owned a mobile phone and almost half of them, were owners of smart phones, teens also owned a tablet computer which were generally used by adults with $23 \%$ and a significant $95 \%$ of them used the internet and similarly, $93 \%$ had a computer or had access to it.

According to (UNICEF, 2011) it is the culture of the youth to adhesive themselves to social network sites, online games, video-sharing sites and gadgets such as iPods and mobile phones to stay connected and to seek entertainment. Hence, lecturers should manipulate wisely these youth craving for technology to be able to keep up with their learning needs. Dehmler (2009) also draws attention to the types of modern technology devices that are most frequently used for communication and entertainment namely the computers which allow internet access, online games, social media and computer games; mobile phones which allow phone calls and text messages; game consoles, television and VCRs or DVD players. Over the years, a tremendous improvement in technology triggered the rise of more modern technology devices such as smart phones and tablets to access social media like twitter and Instagram, smart watches to monitor their health and smart televisions that enable them to watch Netflix and Youtube.

With that in mind, lecturers should realize that students today respond better to the use of technology and with the use of technology in classroom teaching and learning, it subsequently improves their focus and responses towards the subject matter. It is echoed by MacArthur (2008) that the use of interactive media has enhanced skills of social communication among students. It is also found that teaching becomes more interesting when aided by technology. Interactive learning using Kahoot, Quizlet and Thinglink would encourage better transfer of knowledge because the students' minds react better when assisted with the use of modern technology. The reliance and dependence on technology that makes teaching easier and more interesting should be the main focus these days in schools, colleges and universities.

Revathy (2009) reveals there is an awareness among students who are motivated to shine in the corporate world on the importance of learning soft skills such as interpersonal, problem solving and management skills to land themselves in established companies and the study also found that an increasing number of teachers are using Web 2.0 technologies such as podcasts, mobile phones, Wikis, blogs and skype to teach soft skills. According to
Subrahmanyam et al (2000) cognitive researchers state that playing computer games boosts children's ability to read and visualize images. Some computer games and console games are able to have instant positive effects on children's cognitive ability. Problem solving skills could be improved by allowing students to play these games and it is one of the soft skills required by employers in many companies in the world. As mentioned by Matthew (2018) employers are increasingly asking for new hirers who are proficient in soft skills.

(Coffey, 2012) found that the combination of technology and peer-led discussions of literature can greatly improve student engagement and motivation. Besides the classroom learning, small group discussions of literature are extended to unlimited time constraints via wikis, online literature circles, and online book clubs. With these technologies, readers from other schools, states, and countries were able to share their opinions and ideas. These days, lecturers could adapt the same idea by encouraging students to share ideas and opinions via Skype, Telegram or Whatsapp. By doing so, students will be trained to be more confident in voicing out their opinions. Possessing such soft skill would bring benefits when they join the work force.

\subsection{Social Media}

Instagram, Twitter, Facebook, youtube and Snapchat do not need to be introduced to our youth. This is the online platform that allows them to share and exchange ideas, create and broadcast their masterpieces to the virtual world. It also helps to connect and build relationships. Young people are greatly dependent on social media. Some are addicted to mobile phones and develop 'Nomophobia'. It is not uncommon to see young people frequently checking Tweets and status updates to stay connected to one another. Youth receive currents news and are being updated 24 hours a day through social media. Lecturers should be bold and creative to utilize these social media to inject elements of fun and authentic engagement among their students in their teaching. With the use of these social media, lecturers could connect with their students even outside the teaching parameter, as long as it is kept strictly professional. The timid and introverted students would be able to participate actively in discussions via social media. This would help improve their communicative skills which is one of the important soft skills in the career world. Affendi Hama et.al (2012) agreed that people around the world use social media to share information and become closely connected. Social media contribute to enhance communications, allow vast opportunities to obtain information and have become the most sought-after source of entertainment. Lecturers could also encourage the entrepreneurial students to establish better networking to market their products or inventions via social 
media. In a classroom setting, collaboration could exist when a lecturer gains feedback from the students via twitter or other social media. Other than that, lecturers should motivate and allow students to complete their projects while giving some guidance through video conferences which will allow better creativity and ample time outside the classroom setting.

Social Media is great tool in technology which comes with abundance of benefits. Many lecturers have made efforts to utilize them to make their students' learning experiences more colourful. Communication between lecturers and students could be taken to greater heights which is not restricted within the four walls of the classroom. Teachers can connect with their students in a less formal way and this would improve teacher-student relationship. Besides that, students can obtain notes and handouts from a social networking site which is used by their teachers and improve their management skills in monitoring deadlines and updates. Richard Ng and Latifah Abdol Latif (2011) shared how the teaching of Mathematics is eased with the use of social media in a distance learning course whereby students use a specially-created Facebook group to have extended discussion and this has successfully foster better involvements and eliminate feelings of isolation, which is one of the major problems in distance learning courses.

\subsection{Soft Skills}

Soft skills refer to interpersonal skills that enable people to communicate and work well with one another. They are the non-academic skills that students need to be successful in the real working world. These include time-management skills, communication skills, leadership skills and a few others. McMurtrey et al, (2008) agreed that there is a correlation between better soft skills and the employability of graduates who possess sufficient communication skills to communicate with people from diverse backgrounds. In today's competitive working world, employers seek for candidates who are able to deliver their hard skills effectively and at the same time work harmoniously with colleagues and superiors. According to Hewitt Sean (2008), soft skills are nontechnical, intangible, personality specific skills which determine an individual's strength as a leader, listener and negotiator.

An impactful teaching and learning require a technology-savvy lecturer that would be able to bring out the students' hard and soft skills, which are equally important to enable students to perform well in their career.

\section{Issues and Challenges}

Ghavifekr et. Al (2016) have identified several factors that discourage teachers from using technology in their teaching. The teachers feel that they need more training to improve their competency and teaching preparation time. They also believe that using technology in classroom teaching requires better accessibility and network connection.

Today, technology and social media have a huge influence on teenagers. They significantly impact the young people. Technology and social media are useful tools which could make life better. However, students would not be able to maximise the use of technology in improving their soft skills without a full confidence and involvements of their lecturers. Lecturers should remain positive and try their best to utilize technology in their teaching and learning techniques. Instead of rejecting and denying the benefits of technology, lecturers need to explore and embrace technology to help improve their students' soft skills. Therefore, continuous professional development courses to lecturers should be conducted to help them not only learn how to use new technology, but also how to provide meaningful instructions and activities using technology in the classroom and outside the classroom setting.

Another issue that has to be resolved among lecturers in using technology in teaching is their unwillingness to explore and utilize it. Lecturers should renew their commitment to teaching practices that could engage their students in hands-on learning opportunities via technology that could indirectly enhance their soft skills as suggested by Cristen (2009). Lecturers have to realize that in order to create and sustain an interactive teaching and learning environment, the use of technology and social media is imminent.

Insufficient wifi coverage and power source would get in the way of lecturers' access to technology and would create frustration among lecturers and students in optimizing the effective use of technology in teaching and learning. It is the government's duty to look into this problem seriously because one of main contributors for the success of the $21 \mathrm{st}$ century learning is the use of technology. There is no compromise for internet connection as it is exceptionally critical in improving the quality of teaching and learning by elevating communication, broadening knowledge and upgrading the quality of data management as mentioned by Tukun (2011).

Another barrier given by Butler and Sellbom (2002) and Chizmar \& Williams (2001) is the issue of reliability. Most complaints about reliability include hardware failures, incompatible software, poor or slow internet connectivity and outdated software and computers. Unfortunately, these problems still exist in our part of the world today, especially 
in the rural areas. According to Elgar (2009), the effort to expand the use of technology in teaching is a worldwide effort. It is pertinent to ensure all measures are taken to enhance the quality of technology in teaching as technology facilitates interesting, enjoyable and interactive teaching and learning that would definitely engage the young people in it.

\section{Implications and Suggestions}

Technology may not become a substitute to a lecturer but it can be used as a supplementary tool to enhance teaching methods in classroom. Lecturers should discard the "chalk and talk" monotonous and boring method and switch to the fast developing 21 st century technologies and social media. A study conducted by Baytak, Tarman \& Ayas (2011) discovered that students believe that their learning is improved by integrating technology in classroom learning. This is supported by Kevin (2014) who reiterates that technology comes with abundance of benefits whereby it helps elevate student motivation, creates better student engagement, allows active collaboration and enhances handson learning while boosting students' confidence.

The benefits that have been discovered by past researches in utilizing technology in teaching reveal that they bring out positive soft skills among students. Glenn (2008) found that high-performing organizations seek for future employees who have acquired sufficient soft skills to be selected as part of the workforce. It is however recommended that lecturer-student interaction in the social media should be kept strictly professional. Social media should be used appropriately and confined to academic matters only.

Incorporating technology in teaching helps students stay engaged. Therefore, it is important to coordinate teaching with the demands and needs of the students towards a more interactive classroom learning experience. Some recommendations on using technology in teaching softskills are:

\subsection{Skype, WhatsApp, Twitter, Instagram}

Apps such as Skype, WhatsApp, Twitter, Instagram can help establish real-life communication. They allow personal expressions and creativity. Social media apps also allow communications with authentic people outside the classroom or campus. Nowadays job interviews could be carried out using Skype. This is an advantage for students who are not able to travel far for their job interviews.

\subsection{Digital gaming, online videos, podcasts, $3 D$ printers, Bee-Bots}

Online videos, podcasts and digital gaming encourage the development of critical thinking skills. Students are required to make quick and accurate decisions when they play the games. Likewise, 3D printers are useful tools for future engineers, architects and designers in improving their problem-solving skills and enhancing their creativity and innovation. Educational tools such as Bee-Bots also provides colourful, easy-to-operate and friendly little robots that are fun to use in teaching young children about sequencing, estimation and problem-solving.

\subsection{Post-it Notes, I-Cloud, Google Drive}

Technology can be used to instil management skills in students as well as helping lecturers to manage their own time more efficiently. Flipped learning methods use cloudbased platforms that allow learning to take place beyond the classroom whereby content can be accessed by students at anytime, anywhere, as long as they have an internet connection. Nowadays, students use technology to watch recorded lectures prior to going for the lesson to be taught in class and complete the tasks given by lecturers when they come to class. Apps and cloud-based platforms can also be used by students to improve their time management skills whereby they have to keep track of all their notes, documents and images in one central data storage and making it easy to find everything they need for an assignment. This requires proper management of data to ease the process of retrieving information. Students will be more efficient in managing their own notes and data.

\subsection{Pinterest, Dribble, FoodGawker, Hometalk, Fancy, Canva}

Websites and applications such as Pinterest, Dribble, FoodGawker, Hometalk, Fancy and Canva allow students to enhance their creativity. They promote the manipulation of existing information and the opportunities to create one's own tangible products. They are also great platforms to share students' creative innovations. Apart from that, the platforms are also useful for students who possess entrepreneurial interest to market their ideas or products.

\section{Conclusion}

Technology contributes to the improvement of teaching and learning of soft skills. Lecturers and students should learn to accept the benefits that technology brings along. Denial will only hinder the success of the students and the institutions. It is crucial for the government to take extreme measures to make sure that more technologically equipped education institutions are being developed or improved. 
As the industry is seeking for a good combination of hard and soft skills in their future employees, education institutions play an extremely important role in making sure that proper soft skill teaching is carried out to bridge the gap between the industry and academic institutions. As technology becomes the central part of the modern world, educators must be made aware of the abundance of benefits brought by technology to optimize chances for students to successfully acquire a job. Only by integrating technology in teaching and learning and ensuring it as an important part of the learning experience, can lecturers motivate soft skills such as collaboration, communication, critical thinking and creativity to ensure that tomorrow's employees have the complete range of skills required by employers.

\section{References}

[1] Ahmed, F., Capretz, L. F., Bouktif, S., \& Campbell, P. (2012). Soft skills requirements in software development jobs: A cross-cultural empirical study. Journal of Systems and Information Technology, 14(1), 58-81. doi:10.1108/13287261211221137

[2] Affendi Hamat, Mohamed Amin Embi, Haslinda Abu Hassan. (2012). Social Networking Sites among Malaysia University Students. International Education Studies. dx.org/10-5539/ies.v5n3p56

[3] A.T.M Shahjahan, K.Chisty, "Social Media research and its effect on our society" International journal of Information 7 communication Engineering, Vol:8, No:6,2014.

[4] Australian Workforce and Productivity Agency. (2013). ICT Workforce Study. Canberra, Australia: Commonwealth of Australia Retrieved from http://www.awpa.gov.au/publications/Documents/ICTSTUDY-FINAL-28-JUNE2013.pdf

[5] Babbie, E. (1990) Survey Research Methods, Second Edition, Belmont: Wadsworth.

[6] Baytak A, Tarman B. \& Ayas (2011). Experiencing Technology Integration in Education: Children's Perceptions. International Electronic Journal of Elementary Education.

[7] Bin Zhao et al., "Online Detection of Unusual Events in Multimedia via Dynamic Sparse Coding”, 2011.

[8] Blackman, A. (2012). The Immediate Feedback Assessment Technique (IF-AT): An innovative teaching technique for human resource management students. The Business Review, Cambridge, 20(2), 59-72.

[9] Centre for Children and Technology (2005) Critical Issue: Using Technology to Improve Student Achievementt Available at (http://www.info.ncrel.org) Retrieved 21/08/13.

[10] Chan, V. (2011). Teaching oral communication in undergraduate science: Are we doing enough and doing it right? Journal of Learning Design, 4(3), 71-79. doi: 10.5204/jld.v4i3.82

[11] Che Su Mustaffa \& Nan Zakiah Megat Ibrahim. (2014). Persepsi dan penggunaan media sosial dari perspektif ibu bapa: Satu Analisis Kualitatif. Malaysian Journal of Communication, Jilid 30 (Special Issue) 2014, 43-74.

[12] Christen A. (2009). Transforming the Classroom for Collaborative Learning in the 21st Century Techniques. Connecting Education and Careers. 84(1), 28-31.

[13] Coffey, G. (2012). Literacy and Technology: Integrating Technology with Small Group, Peer-led Discussions of Literature. International Electronic Journal of Elementary Education, 4(2), 395-405.

[14] Collins English Dictionary. (2012). Digital Edition (C) William Collins Sons \& Co. Ltd.

[15] Darrel L Butler, Martin Sellborn. (2001). Barriers to Adopting Technology for Teaching and Learning. Educause Quarterly, Vol 25, number 2. ISSN 1528-5324

[16] Dehmle, K.M., (2009) Adolescent Technology Usage, Sleep, Attention and Academics.

[17] Friedman, B., Cox, P., \& Maher, L. (2008). An expectancy theory motivation approach to peer assessment. Journal of Management Education, 32(5), 580-612.

[18] Ghavikefr et.al (2016). M'sian Online Journal of Educational Technology 4(2)38-57. Faculty of Education. University of Malays . Kuala Lumpur.

[19] Glenn, J. L. (2008). The "new" customer service model: Customer advocate, company ambassador. Business Education Forum, 62(4), 7-13.

[20] Harm-Jan Steenhuis \& Erik J. de Bruijn. (2006). High technology revisited: Definition and position. International Conference on Management of Innovation and Technology. 1080-1084.

[21] Haythornthwaite, C., Kazmer, M. M., Robins, J., \& Shoemaker, S. (2000). Community development among distance learners: Temporal and technological dimensions. Journal of Computer-Mediated Communication, 6(1). doi: 10.1111/j.10836101.2000.tb00114.x

[22] Hewitt Sean. (2008). 9 Soft Skills for Success. International Journal of Economics, Commerce and Management. United Kingdom.

[23] Honey,M, Culp,KM, \&Spiehogel,R.(2005). Critical Issue: Using Technology to Improve Student Achievement. New york: North Central Regional Educational Laboratory.

[24] Hunt, S. (2007). Hiring Success: The Art and Science of Staffing Assessment and Employee Selection. San Francisco: John Wiley \& Sons

[25] John F Chizmar, David B. Williams. What do Faculty Want? Educause Quarterly. Vol 24, number 1. ISSN 1528-5324. 
[26] Kevin C. Costley. (2014). The Positive Effects of Technology on Teaching and Student Learning.

[27] Koivusilta, L.K., Lintonen, T.P., \& Rimpela, A.H. (2007). The orientations in adolescent use of information and communication technology: A digital divide by socio demographic background, educational career, and health. Scandinavian Journal of Public Health, 35(1), 95-103.

[28] Kriz, K., \& Qureshi, S. (2009) The Role of Policy in the Relationship between ICT Adoption and Economic Development : A Comparative Analysis of Singapore and Malaysia. Retrieved from http://aisel.aisnet.org/globdev2009/13

[29] Laker, D. R. \& Powell, J. L. (2011). The Differences between Hard and Soft Skills and Their Relative Impact on Training Transfer. Human Resource Development Quarterly. 22(1), 111-122.

[30] Leedy, P.D. \& Ormrod, J.E. (2005) Practical Design, 8th Edition. New Jersey: Pearson Merrill Prentice Hall.

[31] MacArthur (2008). Living and Learning New Media. Summary of Findings from the Digital Youth Project Available at www.macfound.org. Retrieved 21/08/13.

[32] Mahmoudi Sidi Ahmed et al., "Detection of Abnormal Motions in Multimedia", Chania ICMI-MIAUCE'08 workshop, Crete, Greece, 2008.

[33] Matthew T Hora, Ross J. Benbow \& Bailey B. Smolarek. (2016). Rethinking Soft Skills and Student Employability: A New Paradigm for Undergraduate Education. $\quad$ ISSN: 1939-9146. tandfonline.com/1oi/vchn20

[34] McFarlane, D. A. (2008), Effectively Managing The 21st Century Knowledge Worker. Journal of Knowledge Management Practice. 9(1).

[35] McMurtrey, M. E., Downey, J. P., Zeltmann, S. M., \& Friedman, W. H. (2008). Critical skill sets of entry-level IT professionals: An empirical examination of perceptions from field personnel. Journal of Information Technology Education, 7, 101-120.

[36] Mikulec, E, Goniu, N \& Moreno, M (2013) Urban, Suburban, and Rural: Adolescents' use of of preferences for fitness promotion technologies communication. University of Wisconsin school of Medicine: Madison.

[37] Morgan, C. K., \& Tam, M. (1999). Unravelling the complexities of distance education Student attrition. Distance Education, 20(1), 96-108. doi: 10.1080/0158791990200108

[38] Muranda, Z.(2004) Dissertation writing: Concepts and Practice. University of Zimbabwe Publications: Harare.

[39] Musa, A.H., Bahaman, A.S., \& HayrolAzril, M. (2012). Usefulness of ICT Usage Among JKKK members in Peninsular Malaysia. Asian Social Science, 255-266.

[40] Myers, T., Monypenny, R., \& Trevathan, J. (2012). Overcoming the glassy-eyed nod: An application of process-oriented guided inquiry learning techniques in
Information Technology. Journal of Learning Design, 5(1), 12-22. doi: https://www.jld.edu.au/article/view/97.

[41] Portal Rasmi Arkib Negara Malaysia. Kementerian Pelancongan dan Kebudayaan Malaysia. (2015). Perkembangan Telekomunikasi Negara.

[42] Richard Ng, Latifah Abdol Latif ( 2011). Social Media and The Teaching of Mathematics in a Lifelong Learning Environment. The International Life Long Learning Conference.

[43] Revathy (2009). Handbook of Research on Web 2.0 and Second Language Learning.

[44] Roois, Limayem, M. and Salehi - Sangari, E. (2011) Impact of face book usage on student achievement rules off self-regulation and trust. Electronic Journal of Research in Education Psychology, 9 (3)961-994.

[45] S.Shabnoor,S.Tajinder,Social Media its Impact with Positive and NegativeAspects IJCATR, Volume 5- Issue 2, $71-75,2016$

[46] S. Willium, "Network Security and Communication", IEEE Transaction, Vol.31, Issue.4, pp.123-141, 2012.

[47] Saunders M, Lewis, P. and Thornhill, A. (2009) Research Methods for Business Students Fifth.

[48] Snyder, L. A., Rupp, D. E. \& Thornton, G. C. (2006). Personnel Selection Of Information Technology Workers: The People, The Jobs, and Issues for Human Resource Management. In J. J. Martocchio (Ed.), Research in Personnel and Human Resources Management, (Volume 25). Oxford: Elsevier.

[49] Strasburger, V.C., Jordan, A.B. and Donnerstein, E. (2010)American Academy of Paediatrics, Health Effects of Media on Children and Adolescents Volume 1 (4)756767 Edition Pearson Education Limited : England.

[50] Subrahmanyam, K,. Kraut,R.E, Greenfield, P.M and Gross, F(2000) The Impact of Home Computer use on children's activities and Development. Available on http://www.futureofchildren.org Accessed 22/07/13

[51] Tutkun. (2011). Internet Access, Use and Sharing Levels Among Students During the Teaching-Learning Process. The Turkish Online Journal of Education Technology.10(3)

[52] UNICEF (2011) The States of the World's Children. Available at: http://www.unicef.org. Accessed 22/07/13.

[53] Walsham, G. R. D., \& Sahay, S. (2007).Special issue on information systems in developing countries. MIS Quarterly,31(2), 317-326.

[54] Watt,H.J (2010) How does use of the modern technology influence language and literacy development: A review;Contemporary issues in communication science and Disorders. Volume 37, 141- 147.Available at: http://www.asha.com. Accessed 01/08/2013.

[55] Zavodny, M. (2006). Does watching television rot your mind? Estimates of the effect on test scores. Economics of Education Review, 25 (5), 565-573. 